\title{
Single nucleotide polymorphism discovery of peroxisome proliferators- activated receptors gamma gene and its association with carcass traits in duck
}

\begin{abstract}
Peroxisome proliferators-activated receptor gamma (PPAR- $\gamma$ ) is thought to play a critical role in glucose and lipid metabolism and in inflammation control. The objective of this study was to detect the single nucleotide polymorphism (SNPs) in whole coding regions of PPAR-gamma gene with single strand conformation polymorphism (SSCP) in Peking duck Z4, Z2, Hybrid and Cherry Valley duck populations. The results showed that there were two alleles and three genotypes in the experimental populations. And one novel polymorphism, a synonymous mutation G-to-T at 213 of 5th exon, was found. The birds with homozygote (TT) was highest for carcass weight, sebum weight, percentage of sebum, abdominal fat weight, percentage of abdominal fat and IMF in four duck populations; however, for breast muscular weight and carcass net weight, the birds with heterozygote (GT) was highest in them. The association analysis results showed that the SNP of the polymorphism of PPAR- $\gamma$ gene was linked with potential major loci or genes affecting some growth and fatness traits.
\end{abstract}

Keywords: duck (Anas platyrhynchos), PPAR- $\gamma$, SNPs, PCR-SSCP, MAS

\section{Zusammenfassung}

Titel der Arbeit: Identifizierung von Polymorphismen im peroxisome proliferators-activated receptors gamma Gen und ihre Assoziation mit Schlachtkörpermerkmalen bei der Ente

Der Peroxisome proliferators-activated receptor gamma (PPAR- $\gamma$ ) spielt eine entscheidende Rolle im Glukoseund Fettstoffwechsel und bei Entzündungen. Das Ziel dieser Studie war es, Polymorphismen (single nucleotide polymorphism, SNPs) in der gesamten kodierenden Region des PPAR- $\gamma$ mittels Single Strang Conformation Polymorphism (SSCP) Analyse bei den Linien Z4, Z2, Hybrid und Cherry Valley der Pekingente zu detektieren. Zwei Allele und drei Genotypen konnten in den Linien identifiziert werden basierend auf einem synonymen Basenaustausch G-to-T in Position nt 213 im Exon 5. Die homozygot (TT) Enten wiesen das höchste Körpergewicht, sowie Gewichte und Anteile an Talg und Bauchfett und intermuskuläres Fett in den vier Entelinien auf, während das Brustmuskelgewicht und das Schlachtkörpergewicht bei Heterozygoten (GT) am höchsten war. Die Assoziationsanalyse zeigte, dass der SNP im PPAR- $\gamma$-Gen im Zusammenhang mit möglichen Majorgenen oder weiteren Gene für Wachstums- und Fettmerkmale steht.

Schlüsselwörter: Ente (Anas platyrhynchos), PPAR- $\gamma$, SNPs, PCR-SSCP, MAS

\section{Introduction}

Although intensive selection in duck has made great improvement in growth rate and feed efficiency, modern strains of ducks exhibit excessive body fat deposition. That is one of the main problems encountered by the duck industry today, because it has significant negative effects on feed efficiency and causes great economic loss to processing plants. The economic concern and recognition of consumer aversion to excess fatty tissue deposition have led commercial breeders to incorporate significant selection for reduced body fatness in their breeding programs. Although several 
strategies of selection for leanness in meat production have been describes, it is still laborious and expensive to measure fat deposition. Therefore, considerable research effort has been applied to study factors associated with fat deposition and methods to reduce it (SHAHIN et al., 2000; WAWRO et al., 2004). Peroxisome proliferatorsactivated receptors (PPARs) belong to the nuclear receptor superfamily (SCHOONJANS et al., 1996; BRAMFELD et al., 2003). PPARs have been implicated in the regulation of almost every single aspect of lipid metabolism and, consequently, in diseases that involve disturbances in lipid metabolism (obesity, diabetes, atherosclerosis, cardiac failure) (PFEUFFER, 2001; VAN et al., 2002). Three types of PPARs have been characterized: PPAR- $\alpha$, PPAR- $\beta$ (also called PPAR- $\delta$ ) and PPAR- $\gamma$. In chicken, PPAR- $\gamma$ has 6 exons and 5 introns. Research showed that the PPAR- $\gamma$ gene has impact on chicken fat metabolism and SNPs could be used in molecular assistant selection (MAS) as a genetic marker for the chicken fatness traits (LI et al., 2005). However, up to now, the research about SNPs of the PPAR- $\gamma$ gene in duck was not reported. The objectives of the present study were to identify SNPs in the duck PPAR$\gamma$ gene and to evaluate associations between the polymorphisms and growth and fatness traits in four duck populations.

\section{Materials and Methods}

\section{Samples Collection and Preparation}

Blood samples were collected from 384 individuals belongs to four duck populations: Peking duck Z4 (98), Peking duck Z2 (95), Hybrid Peking duck (Z4 $\times$ Z2) (HB) (92) and Cherry Valley duck (99). The blood samples were collected from Institute of Animal Science, Chinese Academy of Agricultural Science. The growth and fatness traits (carcass weight, carcass net weight, breast muscular weight, leg muscular weight, abdominal fat weight (AFW), percentage of abdominal fat (AFP), sebum weight, percentage of sebum weight and intramuscular fat (IMF) in these ducks were collected for statistical analysis. The 384 ducks were slaughtered at the end of 42 days. Genome DNA was obtained by phenol and chloroform $(1: 1)$ extraction, and stored at $-20{ }^{\circ} \mathrm{C}$.

\section{Primer Design and PCR Amplification}

Based upon duck PPAR- $\gamma$ gene sequences (Accession no. EF546801), six pairs of primers (Table 1) were designed to amplify the duck PPAR- $\gamma$ gene whole coding region and detect the single nucleotide polymorphisms of the six exons.

Following optimization, PCR reactions were carried out in a total volume of $15 \mu \mathrm{L}$ with $40 \mathrm{ng}$ of genomic DNA, $0.5 \mathrm{pmol}$ of each of forward and reverse primer, $1.5 \mu \mathrm{L}$ of $10 \times$ buffer, $1.5 \mathrm{mM}$ of $\mathrm{MgCl}_{2}, 0.25 \mathrm{mM}$ of deoxyribonucleorides triphosphate, and $1.5 \mathrm{U}$ of Taq DNA polymerase (Fermentas) on an Eppendorf Mastercycler gradient (Eppendorf). With regard to duck samples, the PCR cycles were $95^{\circ} \mathrm{C}$ for $5 \mathrm{~min}, 31$ cycles of $94{ }^{\circ} \mathrm{C}$ for $30 \mathrm{~s}, 46{ }^{\circ} \mathrm{C}$ for $35 \mathrm{~s}$ and $72{ }^{\circ} \mathrm{C}$ for $30 \mathrm{~s}-$ and final extension step at $72{ }^{\circ} \mathrm{C}$ for $10 \mathrm{~min}$.

\section{Single Stranded Sonformation Polymorphism (SSCP) and Sequencing}

Adiquots of $4 \mu \mathrm{L}$ PCR products were mixed with $10 \mu \mathrm{L}$ denaturing solution $(98 \%$ formamide, $25 \mathrm{mM}$ EDTA, $0.025 \%$ xylene-cyanole and $0.025 \%$ bromophenol blue), 
heated for $10 \mathrm{~min}$ at $98{ }^{\circ} \mathrm{C}$ and cooled on wet ice (SUN et al., 2002). Denatured PCR products were subjected to $10 \%$ acrylamide:bisacrylamide $(29: 1)$ gels in $1 \times \mathrm{TBE}$ buffer and constant voltage $(160 \mathrm{~V})$ for $15-16 \mathrm{~h}$. The gel was stained with $0.1 \%$ silver nitrate. Three PCR fragments from different SSCP patterns in different populations were sun-cloned to T-vector (Takara, China). Sequencing reactions were performed with BigDye terminator chemistry and resolved on an ABI PRISM 3730 DNA sequencer. All fragments were sequenced in both directions. The BLAST algorithm was used to search the NCBI GenBank (http://www.ncbi.nlm.nih.cov/) databases for homologous sequences.

Table 1

Primers for PPAR- $\gamma$ gene and PCR analysis parameters established for duck (Primer und PCR-Bedingungen für die Analyse des PPAR- $\gamma$ Gens bei der Ente)

\begin{tabular}{|c|c|c|c|}
\hline Exon & $\begin{array}{l}\text { Fragment } \\
\text { length }(b p)\end{array}$ & Primer sequence & $\begin{array}{l}\text { Annealing } \\
\text { temperature }\left({ }^{\circ} \mathrm{C}\right)\end{array}$ \\
\hline 1 & 222 & $\begin{array}{l}\text { Forward: 5'-ATGGTTGACACAGAAATGCC-3' } \\
\text { Reverse: 5'-ACTTTGGCAATCCTGGAG-3' }\end{array}$ & $x_{2}+2$, \\
\hline 2 & 171 & $\begin{array}{l}\text { Forward: 5'-GTGCAATCAAAATGGAGCC-3' } \\
\text { Reverse: 5-CCTTACAACCTTCACATG-3' }\end{array}$ & 55 \\
\hline 3 & 138 & $\begin{array}{l}\text { Forward: 5'-TAAGGGCTTTTCGAAGAACCAT-3' } \\
\text { Reverse: 5'-TGTGTGACATTCCAACAGCAA-3' }\end{array}$ & 57 \\
\hline 4 & 192 & $\begin{array}{l}\text { Forward: 5'-TCAGGTTTGGGCGAATGC-3' } \\
\text { Reverse: 5'-TGTCGTTTTTCCTGTCAAGATCGC-3' }\end{array}$ & 57 \\
\hline 5 & 450 & $\begin{array}{l}\text { Forward: 5'-CATTTGTTATTTATGACATG-3' } \\
\text { Reverse: 5'-CTCCGCTTAGTATAATGAC-3' }\end{array}$ & 46 \\
\hline 6 & 241 & $\begin{array}{l}\text { Forward: 5'-ACCGCCCAGGTTTGTTA-3' } \\
\text { Reverse: 5'-AGTCTTTATAGATTTCTTG-3' }\end{array}$ & 51 \\
\hline
\end{tabular}

\section{Statistical Analysis}

$\chi 2$ tests were used to determine if the individual variant was in Hardy-Weinberg equilibrium. The genotype and allele frequency distributions were compared by Chi-square test.

The traits were compared between the genotypes. The association between PPAR- $\gamma$ and live weight (42 days), carcass weight, carcass net weight, breast muscular weight, breast muscular rate, leg muscular weight, leg muscular rate, abdominal fat weight (AFW), percentage of abdominal fat (AFP), sebum weight, percentage of sebum and IMF was evaluated according to one-way analysis, using the following model:

$$
\mathrm{Y}=\mu+\mathrm{G}+\mathrm{L}+\mathrm{G} \times \mathrm{L}+\mathrm{e}
$$

where: $Y$ - dependent variable (analyzed traits), $\mu$ - overall mean, $G$ - genotype of PPAR- $\gamma$ exon-5 (AA, AB and BB), L - duck population, $\mathrm{G} \times \mathrm{L}$ - interactions between genotype and duck population (all fixed effects), e - random error.

Difference between genotypes was determined by least square analysis.

\section{Results and Discussion}

Single Nucleotide Polymorphism in Exon-5 of the PPAR- $\gamma$ Gene

Amplicons of the expected size were obtained from duck DNA using different primers. These were identified by PCR-SSCP. The results of exon- 1 to exon- 4 and exon-6 of PPAR- $\gamma$ showed no polymorphism. The amplicons of exon-5 were approximately $450 \mathrm{bp}$ in size and exhibited polymorphism in different individuals and 
populations. Three band patterns could be identified in exon-5 of PPAR- $\gamma$ gene (Figure 1), which were the products of two alleles ( $\mathrm{G}$ and $\mathrm{T})$.

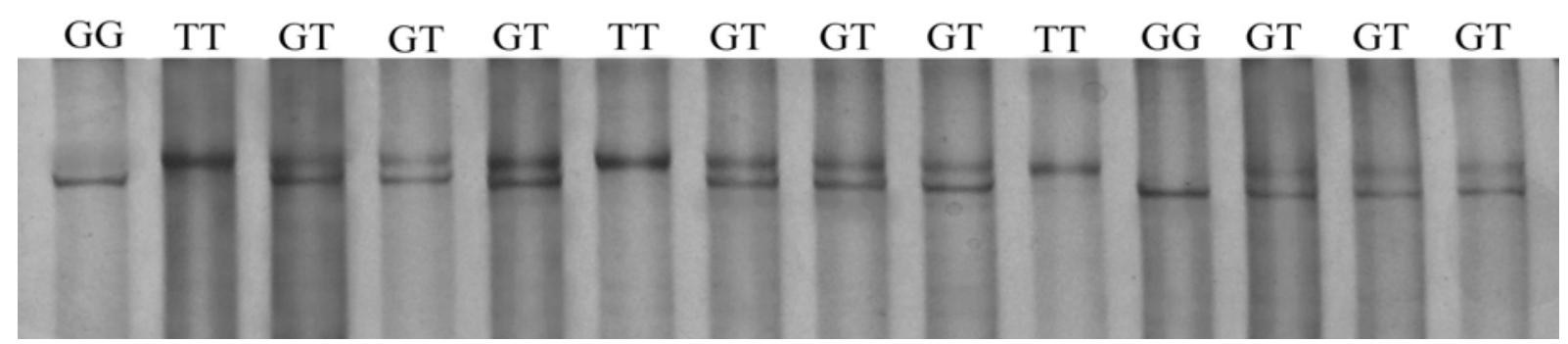

Fig. 1: PCR-SSCP band pattern on a $10 \%$ non-denaturing polyacrylamide gel. The GG genotype has one band which running fast; the TT genotype has one band which running slow; the GT genotype have two bands which one running slow and the other running fast.

(PCR-SSCP Bandenmuster im $10 \%$ nicht-denaturierenden Polyacrylamidgel)

\section{DNA Sequencing}

The sequencing results were compared with the coding region sequence of duck (Accession no.EF546801) and showed: only one SNPs Ex5_213 G-to-T was detected in 384 unrelated duck from four populations (Z4, Z2 and HB Peking duck and Cherry Valley duck). But the G-to-T mutation in the $213^{\text {th }}$ nucleotide of the exon-5 identified a silent allele at PPAR- $\gamma$ locus: ACG (Thr) -ACT (Thr) at position 311 amino acid.

\section{Allele and Genotype Distribution of PPAR- $\gamma$ Gene Exon-5}

In three Peking duck populations, genotype frequency of GG was highest, however, in Cherry Valley duck population, the GT was highest. The G allele frequencies for the exon-5 of PPAR- $\gamma$ gene in the analyzed populations were $0.5714,0.6316,0.5543$ and 0.6162 for Peking duck Z4, Z2, HB and Cherry Valley duck populations, respectively. The genotype distributions of Peking duck Z4, Z2 and HB in disagreement with Hardy-Weinberg equilibrium $(\mathrm{P}<0.05)$ except Cherry Valley duck population (Table 2 ). For the PPAR- $\gamma$ gene, Hardy-Weinberg equilibrium was not fulfilled in Peking duck Z4, Z2 and Hybrid populations. One explanation could be they were suffered intensive selection during the long term commercial breeding. In selected populations, deviations of genotype frequencies from the Hardy-Weinberg equilibrium should be expected for loci with impact on traits under selection (GOLIASOVA et al., 2004).

\section{Table 2}

Allele and genotype frequencies of the SNP in exon 5 of PPAR- $\gamma$ gene in four duck populations (Allel- und Genotypfrequenzen für den SNP im Exon 5 des PPAR- $\gamma$ Gens bei vier Entenlinien)

\begin{tabular}{cccccccc}
\hline \multirow{2}{*}{ Population } & \multirow{2}{*}{ Number } & \multicolumn{3}{c}{ Genotype frequencies } & \multicolumn{2}{c}{ Allele frequencies } & \multirow{2}{*}{$\chi^{2}(\mathrm{HWE})$} \\
& & $\mathrm{GG}$ & $\mathrm{TT}$ & $\mathrm{GT}$ & $\mathrm{G}$ & $\mathrm{T}$ & \\
\hline Z4 & 98 & 0.4388 & 0.2959 & 0.2653 & 0.5714 & 0.4286 & $21.0597^{* *}$ \\
Z2 & 95 & 0.4632 & 0.2 & 0.3368 & 0.6316 & 0.3684 & $7.5392^{* *}$ \\
CV & 99 & 0.3636 & 0.1313 & 0.5051 & 0.6162 & 0.3838 & 0.3891 \\
HB & 92 & 0.3696 & 0.2608 & 0.3696 & 0.5543 & 0.4457 & $6.1018^{* *}$ \\
\hline
\end{tabular}

$\chi 2\left(\right.$ HWE) $=$ Hardy-Weinberg equilibrium $\chi^{2}$ value; Z4=Peking duck Z4; Z2=Peking duck Z2; CV=Cherry Valley duck; HB=hybrid Peking duck of $\mathrm{Z} 4 \times \mathrm{Z} 2 ;{ }^{* *} \mathrm{P}<0.01$ and the SNP locus in the population were not at Hardy-Weinberg equilibrium

Allelic Effect of the PPAR- $\gamma$ Gene Exon-5 on Some Growth and Fatness Traits The candidate gene approach is a very powerful method to investigate associations of gene polymorphisms with economically important traits in farm animals (ROTHSCHILD et al., 1997; SCHWERIN, 2003). Many studies were reported that PPAR gene was a candidate gene associated with the fatness traits in domestic animal 
and poultry (e.g., MENG et al., 2002; BRAMFELD et al., 1980; LI et al., 2005; XIE et al., 2005). In this study, the PPAR- $\gamma$ gene was selected as a candidate gene to investigated associations of gene polymorphisms with some growth and fatness traits in duck populations.

The allelic effects of the PPAR- $\gamma$ gene exon- 5 on some growth and fatness traits in 384 samples of four duck populations were presented in Table 3. For growth and fatness traits with significant differences between genotypes, the allelic effect of carcass weight, breast muscular weight, carcass net weight, sebum weight, AFW, percentage of sebum, AFP and IMF acted in a dominant mode. The birds with homozygote (TT) had significant higher than heterozygotes (GT) and the inbred homozygotes (GG) for the carcass weight, sebum weight, percentage of sebum, abdominal fat weight and percentage of abdominal fat. However, for breast muscular weight, the birds with heterozygote (GT) had significant higher than the inbred homozygotes (GG). The birds with heterozygotes (GT) had significant higher than homozygotes (TT) and inbred homozypotes (GG) for carcass net weight. For IMF, the homozygotes (TT) had higher than heterozygotes (GT). Furthermore, no significant association of different genotypes with other traits were detected $(\mathrm{P}>0.05)$. The results indicated that $\mathrm{TT}$ genotype linked strongly with the QTL controlling fatness traits. Therefore, it was presumed that it may have a QTL controlling fatness in the region and allele $\mathrm{T}$ was dominant to $\mathrm{G}$ associated with fat.

\section{Table 3}

Least square analysis between exon 5 of PPAR- $\gamma$ and growth and fatness traits in ducks (Least square means für Wachstums- und Fettmerkmale in Abhängigkeit vom Genotyp)

\begin{tabular}{lrrr}
\hline \multicolumn{1}{c}{ Growth or fatness trait } & $\begin{array}{c}\text { Genotype GG } \\
(\text { Mean } \pm \text { S.E) }(\mathrm{n}=157)\end{array}$ & $\begin{array}{c}\text { Genotype TT } \\
(\text { Mean } \pm \text { S.E.) }(\mathrm{n}=85)\end{array}$ & $\begin{array}{c}\text { Genotype GT } \\
(\text { Mean } \pm \text { S.E) }(\mathrm{n}=142)\end{array}$ \\
\hline Carcass weight (g) & $2337.00 \pm 34.80^{\mathrm{b}}$ & $2486.57 \pm 44.77^{\mathrm{a}}$ & $2247.56 \pm 44.20^{\mathrm{b}}$ \\
Breast muscular weight (g) & $212.91 \pm 4.94^{\mathrm{b}}$ & $215.91 \pm 6.00^{\mathrm{ab}}$ & $226.49 \pm 4.88^{\mathrm{a}}$ \\
Leg muscular weight (g) & $136.09 \pm 7.09$ & $129.85 \pm 1.90$ & $132.57 \pm 1.44$ \\
Carcass net weight (g) & $1303.77 \pm 35.58^{\mathrm{b}}$ & $1251.01 \pm 42.84^{\mathrm{b}}$ & $1439.74 \pm 50.13^{\mathrm{a}}$ \\
Sebum weight (g) & $553.00 \pm 8.97^{\mathrm{b}}$ & $635.55 \pm 12.11^{\mathrm{a}}$ & $568.98 \pm 10.25^{\mathrm{b}}$ \\
Abdominal fat weight (g) & $41.57 \pm 0.91^{\mathrm{b}}$ & $56.14 \pm 1.60^{\mathrm{a}}$ & $42.09 \pm 1.38^{\mathrm{b}}$ \\
Sebum (\%) & $47.29 \pm 0.71^{\mathrm{b}}$ & $54.87 \pm 1.03^{\mathrm{a}}$ & $48.87 \pm 1.02^{\mathrm{b}}$ \\
Abdominal fat (\%) & $3.57 \pm 0.08^{\mathrm{b}}$ & $4.85 \pm 0.14^{\mathrm{a}}$ & $3.65 \pm 0.13^{\mathrm{b}}$ \\
Intramuscular fat (\%) & $5.35 \pm 0.16^{\mathrm{ab}}$ & $5.64 \pm 0.21^{\mathrm{a}}$ & $4.99 \pm 0.13^{\mathrm{b}}$ \\
\hline Differ & &
\end{tabular}

Different superscript letters (a, b, c) were significantly different (LSD test, $\mathrm{P}<0.05$ ) in genotypes GG, TT and GT; n: number of the genotype in the population

There are many studis showing that PPAR- $\gamma$ gene was association with lipid metabolism. Gene ablation experiments in mice showed that PPAR- $\gamma$ is required for the development of placental blood vessels and fatness tissue (ROSEN et al., 1999; KUBOTA et al., 1999; BARAK et al., 1999). In addition to these developmental roles, PPAR- $\gamma$ promotes lipid storage during adipogenesis (DESVERGNE et al., 1999) and inhibits inflammation by causing apoptosis in macrophages (SPIEGELMAN, 1998; CHINETTI et al., 1998). In this study, the unique population design provided an opportunity to detect the interaction between the PPAR- $\gamma$ gene and genetic background of four duck populations on growth and fatness traits. These phenotypic differences among the four populations likely reflect their different genetic background. Strong interactions between the PPAR- $\gamma$ gene and genetic background were detected for the associations between the genotypes and growth and fatness traits in four duck populations, which illustrates the importance of defining gene effects in specific populations before future applications using marker assisted selection program. 
The results of this study showed that the single nucleotide polymorphism at 213 nucleotide in exon-5 was strongly associated with sebum weight, percentage of sebum, abdominal fat weight and percentage of abdominal fat in four duck populations, and therefore, with lipid metabolism. It was also significant associated with carcass weight in Z2 and Z4 populations. An explanation for the results was probably due to the low animal numbers. So, we conjecture the PPAR- $\gamma$ gene may be a major candidate gene or linked to major candidate gene that impact duck lipid metabolism and the SNP could be used in molecular assistant selection (MAS) as a genetic marker for duck fatness traits. This result was consistent with the study in chicken (LI et al., 2005).

\section{Interaction between the PPAR- $\gamma$ Gene exon-5 and genetic background of four duck populations}

The interactions between the genotypes of PPAR- $\gamma$ gene exon-5 and genetic background of four duck populations were showed in Table 4. For the sebum weight, percentage of sebum, abdominal fat weight and percentage of abdominal fat, interactions between the genotypes and populations were significant different $(\mathrm{P}<0.05)$.

Table 4

Effects (P-value) of polymorphism of PPAR- $\gamma$ gene exon-5 on duck growth and fatness traits (Effekte [P-Werte] des SNP in Exon 5 des PPAR- $\gamma$ auf Wachstums- und Fettmerkmale bei der Ente)

\begin{tabular}{|c|c|c|c|}
\hline Growth or fatness trait & Genotype & Population & Genotype $\times$ Population \\
\hline Carcass weight $(\mathrm{g})$ & 0.0407 & $<0.0001$ & 0.1533 \\
\hline Breast muscular weight (g) & 0.0442 & $<0.0001$ & 0.6654 \\
\hline Leg muscular weight $(\mathrm{g})$ & 0.7473 & 0.2991 & 0.7751 \\
\hline Carcass net weight (g) & 0.0476 & $<0.0001$ & 0.2975 \\
\hline Sebum weight (g) & $<0.0001$ & $<0.0001$ & 0.003 \\
\hline Abdominal fat weight (g) & $<0.0001$ & $<0.0001$ & $<0.0001$ \\
\hline Sebum $(\%)$ & $<0.0001$ & $<0.0001$ & $<0.0001$ \\
\hline Abdominal fat $(\%)$ & $<0.0001$ & $<0.0001$ & $<0.0001$ \\
\hline Intramuscular fat $(\%)$ & 0.5534 & $<0.0001$ & 0.0618 \\
\hline
\end{tabular}

\section{References}

BARAK, Y.; NELSON, M.C.; ONG, E.S.; JONES, Y.Z.; RUIZ-LOZANO, P.; CHIEN, K.R.; KODER, A.; EVANS, R.M.:

PPAR gamma is required for placental, cardiac, and adipose tissue development. Mol. Cell. 4 (1999), 585-595

BOTSTEIN, D.; WHIT, R.L.; SKOLNICK, M.; DAVIS, R.W.:

Construction of a genetic linkage map in man using restriction fragment length polymorphisms. Americ. J. Hum. Gen. 32 (1980), 314-331

BRAMFELD, J.M.; FAHEY, A.J.; LANGLEY-EVANS, S.C.; BUTTERY, P.J.:

Nutritional hormonal control of muscle growth and fat deposition. Arch. Tierz. 46 (2003) Special Issue, 143-156

CHINETTI, G.; GRIGLIO, S.; ANTONUCCI, M.; TORRA, I.P.; DELERIVE P.; MAJD, Z.; FRUCHART, J.C.;

CHAPMAN, J.; NAJIB, J.; STAELS, B.:

Activation of proliferator-activated receptors alpha and gamma induces apoptosis of human monocytederived macrophages. J. Biol. Chem. 273 (1998), 25573-25580

DESVERGNE, B.; WAHLI, W.:

Peroxisome proliferators-activated receptors: nuclear control of metabolism. Endoc. Rev. 20 (1999), 649-688

GOLIASOVA, E.; WOLF, J.:

Impact of the ESR gene on litter size and production traits in Czech Large White pigs. Anim. Gen. 35 (2004), 293-297 
KUBOTA, N.; TERAUCHI, Y.; MIKI, H.; TAMEMOTO, H.; YAMAUCHI, T.; KOMEDA, K.; SATOH, S.; NAKANO, R.; ISHII, C.; SUGIYAMA, T.; ETO, K.; TSUBAMOTO, Y.; OKUNO, A.; MURAKAMI, K.; SEKIHARA, H.; HASEGAWA, G.; NAITO, M.:

PPAR gamma mediates high-fat diet-induced adipocyte. hypertrophy and insulin resistance. Mol. Cell. 4 (1999), 597-609

LI, H.; LI, Z.; MENG, H.; ZHAO, J.G.:

Single nucleotide polymorphism on peroxisome proliferators-activated receptor genes associated with fatness traits in chicken. Asian-Australasian J. Anim. Sci. 18 (2005), 1221-1225

MENG, H.; WANG, G.H.; WANG, Q.G.; ZHAN, J.G.; GU, Z.L.; WANG, Y.X.; LI, H.:

Studies of single nucleotide polymorphism of PPAR gene and its associations with fattiness trait in chicken. Acta Gen. Sinica 29 (2002), 119-123

PFEUFFER, M.:

Physiologic effects of individual fatty acids in animal and human body with particular attention to coronary heart disease risk modulation. Arch. Tierz. 44 (2001), 89-98

ROSEN, E.D.; SARRAF, P.; TROY, A.E.; BRADWIN, G.; MOORE, K.; MILSTONE, D.S.; SPIEGELMAN, B.M.; MORTENSEN, R.M.:

PPAR gamma is required for the differentiation of adipose. Tissue in vivo and in vitro. Mol. Cell. 4 (1999), 611-617

ROTHSCHILD, M.F.; SOLLER, M.:

Candidate gene analysis to detect traits of economic importance in domestic livestock. Probe 8 (1997), $13-20$

SCHOONJANS, K.; STAELS, B.; AUWERX, J.:

The peroxisome proliferator-activated receptors (PPARs) and their effects on lipid metabolism and adipocyte differentiation. Biochem. Biophys. Acta 1302 (1996), 93-109

SCHWERIN, M.:

Functional genomics - new possibilities for animal breeding and husbandry. Arch. Tierz. 46 (2003), Special issue, 89-93

SHAHIN, K.A.; SHEMEIS, A.R.; ABDALLAH, O.Y.; SALEH, K.:

Effects of genetic control subcutaneous fat deposition via using restricted selection indexes on live performance and carcass characteristics of Pekin ducklings. Arch. Tierz. 43 (2000), 69-77

SPIEGELMAN, B. M.: PPAR $\gamma$ in monocytes: less pain, any gain? Cell. 93 (1998), 153-155

SUN, H.S.; ANDERSONA, L.L.; YU, T.P.; KIM, K.S.; KLIND, J.; TUGGLE, C.K.:

Neonatal Meishan pigs show POU1F1 genotype effects on plasma GH and PRL concentration. Anim. Reprod. Sci. 69 (2002), 223-237

TONTONOZ, P.; HU, E.; SPIEGELMAN, B.M.:

Stimulation of adipogenesis in fibroblasts by PPAR- $\gamma 2$, a lipid-activated transcription factor. Cell. 79 (1994), 1147-1156

VAN, B.M.; VAN, V.G. J.; GILDE, A.J.; LINDHOUT, M.; VAN, K.A.J.M.:

Peroxisome proliferators-activated receptors: lipid binding proteins controlling gene expression. Mol. Cell. Biochem. 239 (2002), 131-138

WAWRO, K.; WILKIEWICZ-WAWRO, E.; KLECZEK, K.; BRZOZOWSKI, W.:

Slaughter value and meat quality of Muscovy ducks, Pekin ducks and their crossbreeds and evaluation of the heterosis effect. Arch. Tierz. 47 (2004), 287-299

XIE, X.L.; WANG, D.; WANG, H.:

Relationship between genotype of PPAR $\alpha$ and body fat traits in AA broiler line. Acta Vet. Zoot. Sinaca 36 (2005), 1261-1264

Received: 2007-07-18

Accepted: 2008-04-21

Corresponding author:

Prof. Dr. XIAOLIN LIU

College of Animal Science and Technology

Northwest A\&F University

Yangling Shaanxi 712100

China

email: xiaolinliu2000@sina.com 